\title{
The Comparison of Two Different Election Campaign Films in Terms of Their Approaches towards National History and Development
}

\author{
Yusuf DEVRAN ${ }^{1} \&$ Fahad SHAHZAD ${ }^{2}$
}

\begin{abstract}
The paper is a comparative analysis of two popular mass media campaign films of Turkey and France. The 1988 presidential election campaign film of French Socialist Party "La France Unie" and 2016 presidential election campaign film of "AK Party" the "Anka Kuşu" from Turkey have been analyzed in terms of their approaches to history and development. The written and visual elements of these films were analyzed by semiotics, rhetoric and discourse analysis methods, and their approaches to the national history and development of both parties were revealed.
\end{abstract}

Key Words: AK Party, Turkey, Political Communication, Election Campaigns, Anka Kuşu Film, National History

\section{İki Farklı Siyasal Seçim Kampanyası Filminin Gelişmeye, Kalkınmaya ve Milli Tarihe Bakışları Bakımından Karşılaştırılması}

Öz

Bu çalıșmada Türkiye'de ve Fransa'da popüler olan iki farklı seçim kampanyası filmi karşlaştırmalı olarak analiz edilmiştir. Fransız Sosyalist Partisi’nin 1988 yapımı "La France Unie" ve AK Parti’nin 2016 yapımı "Anka Kuşu” isimli Başkanlık Seçimi temalı filmleri bu siyasi partilerin tarihe ve kalkınmaya yönelik yaklaşımları açısından incelenmiştir. Bu filmlerin yazılı ve görsel unsurları göstergebilim, retorik ve söylem çözümleme yöntemleriyle analiz edilmiş ve her iki partinin ulusal tarihlerine ve gelişimlerine olan yaklaşımları ortaya konulmuştur.

Anabtar Kelimeler: AK Parti, Türkiye, Siyasal İletişim, Seçim Kampanyaları, Anka Kuşu Filmi, Ulusal Tarih

Atıf İçin / Please Cite As:

Devran, Y., \& Shahzad, F. (2020). The comparison of two different election campaign films in terms of their approaches towards national history and development. Manas Sosyal Arasstrmalar Dergisi, 9(1), 301-312.

Geliş Tarihi / Received Date: 27.03.2019

Kabul Tarihi / Accepted Date: 25.11.2019

\footnotetext{
${ }^{1}$ Prof. Dr. - Marmara University, Faculty of Communication, yusufdevran@gmail.com ORCID: 0000-0001-6430-1943

2 PhD Student - Marmara University, Faculty of Communication, fahadshahzadwaraich@gmail.com ORCID: 0000-0001-5090-5834
} 


\section{Introduction}

The article is an attempt to conduct an analysis of French and Turkish popular political parties' approach towards history and development through their election campaigns. For the purpose 1988 presidential election campaign film of French Socialist Party "La France Unie" and 2016 presidential election campaign film of Turkish AK Party "Anka Kuşu” were analyzed.

The French film starts by French Revolution and covers all social, political, military, scientific, artistic, cultural and other civilizational contributions by French nation. On the other hand, the Turkish film possesses great gap in its civilizational representation. At least according to the film only army operations such as the Malazgirt war, the establishment of the Ottoman Empire, the conquest of Istanbul, Sultan Selim the Stern's expedition to Egypt, the establishment of the republic of Turkey was the successes and infrastructural development by AK Party is the only development.

Political parties broadcast their political messages during the election campaigns in the form of short films. The purpose of these films is dissemination of their ideology and point of view with followers. This is the reason that the campaign films have great significance in terms of their message delivery and convincing the audience. Different visuals and sounds are put together in a special order to create the messages that is why the selection of symbols, icons or indexical signs and sound items are crucial, especially because they may contribute to the meaning as a whole. On the other hand how the followers read and comprehend the messages is another significant point. Everybody has its own intellectual background and ideology. In the study the focus has been kept on how AK-Party and Socialist Party of France have constructed their popular campaign films. And the analysis of approach of both parties towards national history and their role into its construction is another significant point.

\section{Importance of Election Campaign Films}

There is variety of academic works on the importance of election campaigns and it is difficult to mention all in a limited article. Especially the American election campaigns have been well studied and grab worldwide attention besides the fellowship by democratic parties. Eric Alterman's "When Presidents Lie", Stefan Halper and Jonathan Clarke's "America Alone", Kathryn Dunn Tenpas's "Presidents as candidates", Richard Lau and David Redlawsk" "How Voters Decide" and Dennis Johson's "No place for Amateurs" are few popular examples.

By the political campaigns one can also interpret the approach of party leadership towards society and the possible policies and trends in the coming government.

In an online publication on "the content and effect of political advertising in US campaigns", Mathew P. Motta and Erika Franklin Flower (2016) have concluded that "advertising effects often vary in relation to characteristics of the messages being aired, the individuals view them in contextual factors" related to the campaign just generally. Studies suggest that advertising has persuasive but conditionally (volume and negativity) short-lived influence on citizens (para. 3). In this context the central goal of any campaign is to persuade the electorate for adopting certain political attitude and mobilize itself towards the line of political elite of society. A campaign that can cover all departments of the society where party wants to work or have worked before is also important. Creating awareness about public affairs, the impressions that citizens have about politicians, and the extent to which they place trust in the political processes and the institutions are also important because eventually political campaigns first and foremost the hope builders for voters to support their candidate at the polls (para. 9).

"To understand the impact of electronic media, of course, we need to look beyond their mere existence to their social organization. The electronic media was organized originally in Europe under political authority" (Esser \& Pfetsch, 2004, p. 34). On the sphere 1989's French election campaign film "de Mitterrand" could be taken as an example for quotation where the progress in every section of the society has efficiently been shown in one and half minute campaign film. Besides political, military leadership the sports, artistic, cultural, showbiz and media leadership has been shown efficiently.

As the cultural factors could be different so the comparative studies could be helpful to overcome the expected loopholes in every society. In this scenario Frenk Esser and Barbara Pfetsch (2004) in the work under the title "Comparing Political Communication" says "The structure of political communication implies the institutional and cultural contexts of the political system and the media system on the macro- and meso- levels. Michael Gurevitch and Jay Blumler suggest as a future trajectory of 
comparative political communication: 'Just as comparative communication research can be regarded as a subset of the comparative study of culture, comparative political communication research should be seen as the examination of political cultures and their impact on political communication in different societies'. The main objective of Michael Gurevitch and Jay Blumler is to identify key dimensions, which are applied in various societies to regulate political communication". Therefore the relationships between political culture and political communication which include the construction and encoding of political messages, their reception by the public, the changeable relationships between political culture and the culture of journalism, citizens and political elites and between media and political institutions lie essentially (p. 18).

Esser and Pfetsch (2004) further emphasize that the study of political communication culture enables us for comparative analysis of political content and its impact. They also make a solid functional argument that in modern Western society a specific environment of interaction between political commentators and journalists has been developed. In the result, media and politics have overlapped and eventually determines the patterns and outputs of political communication. They further explain that although this type of political communication culture varies from society to society especially in the structural arrangements, media system and local political factors but due to the purpose or results they could be studied for comparison (p. 19).

Indeed after the Cold War the dramatic changes in human development have broken down the old tripartite distinctions between postindustrial, post-communist, and developing societies. Even the established democracies, consolidating democracies, and non-democratic societies and their political messaging have been quite changed. Norris says (2016) the process of globalization and the rise of new information technologies have also transformed the subject. But particularly orient society still stuck in the rut of studying the mass media and its content within particular modern nation-states paradigm (p. 135).

\section{Zümrüdü Anka or the Turkish States Rising From Their Ashes}

The movie Zümrüdü Anka (Phoenix) starts with Sultan Alparslan entering Anatolia from Malazgirt in 1071, continues with the depiction of Ottoman Empire and the Republic Period and ends with the ruling AK Party (Justice and Development Party) and Recep Tayyip Erdoğan. Throughout the movie, Alparslan, Malik-Shah, Osman Gazi, Mehmet the Conqueror, Sultan Selim the Stern, Süleyman the Magnificent (with indicators), Sultan Abdulhamid, Mustafa Kemal Atatürk (with indicators) and Recep Tayyip Erdoğan are presented as leaders with determining roles in the foundation years, present time and future of Turkey.

Although these leaders are very well known by the Turkish nation, the meaning of this bird phoenix in mythology must be shared to understand the message of the movie, since the bird is used as a strong metaphor and the history of Turkey is associated with the life of this bird throughout the movie.

Phoenix is the leading figure of the Simurgh legend and is known as the symbol of rebirth, revival and rising from its ashes. The bird is believed to live in the Mount Kaf. The most important myth of this bird is that at the end of its life it burns itself and its nest and gets rebirth from the ashes (Eskier, 2019).

As the legend goes, the master of all birds, Simurgh or Phoenix lived in the branches of the Tree of Knowledge and thus was all-knowing. Other birds had faith in Simurgh and thought that it would save them all from their ordeals. They all waited for Simurgh to come whenever something went wrong in the world of birds. However, some got suspicious as Simurgh did not appear and finally they gave up all hope. One day, a flight of birds in a distant country found a feather from Simurgh. Convinced about its existence, all birds gathered and decided to appear before Simurgh to ask for help to end their ordeals. Yet, Simurgh's nest was on top of the Mount Kaf with foothills over the clouds. They had to pass through seven fathomless valleys. Upon this, all birds started to fly into the sky. Some got tired and fell down on the way. First, Nightingale turned back remembering its love for rose; Parrot used its beautiful feathers as excuse to give up this journey (in fact, it was caged due to its feathers); Eagle could not give up on its kingdom high in the sky; Owl missed its ruins and Heron its clay swamp. So, their number fell as they flew over the seven valleys. The Sixth Valley was called the valley of "confusion" and the seventh "evanescence". Only thirty birds managed to pass through these valleys and arrive at the Mount Kaf. When they found Simurgh's nest, they learnt that "Simurgh-Phoenix" meant "Thirty Birds". All of them together were now Simurgh. And each was individually "Simurgh" (https://www.dogaustu.net/, Retrieved: 19.03.2019). 
Called as Simurgh in Iranian mythology, this bird is known as Phoenix in Greek mythology, Anka in Arab and Garuda in Indian mythology. In Turkish mythology, on the other hand, such birds are collectively named after Alpine Dark Birds (Eagles) or Tuğrul. The word Zümrüdü Anka is derived by adding the word zümrüt (emerald) to the Arabic word Anka due to the color of the bird (Duymaz, 1998, p. 93).

Phoenix is used in Sheikh Galib's Collected Poems in reference to uniting with the beloved: "Your flame shall burn me such deep that a colorful Phoenix shall rise from my own ashes." In this couplet, the poet depicts himself burning in the fire of love and being reborn from his ashes just like a Phoenix (Tansu \& Güvenç, 2017, p. 794).

According to Greek mythology, Phoenix threw itself to fire and burnt to ashes after a lifetime of nearly five centuries. After being reborn from its ashes, it became immortal. Another legend suggests that the bird was a part of the sun, revolving and living together with it. So, the bird rises and sets together with the sun. At every sunrise, the bird returns to life and turns into ash with every sunset (Tansu \& Güvenç, 2017, p. 784).

\section{The Power of the Script and the Spirit of the Voiceover}

The movie script is written in poem form and vocalized by President Recep Tayyip Erdoğan. This poetic emphasis adds an intense emotional meaning to the script. With its heroic connotation, the Plevne Anthem in the background consolidates this emotionality. The Plevne Anthem connotates a historic war and heroism, however it does not cover all periods depicted in the movie. Nevertheless, such music is preferred since the foundation of Turkey is described in the movie.

The Plevne Anthem symbolizes resilience and courageous struggle of Turks against attacks. The music is aspired to demonstrate Erdoğan's resistance story standing upright against the entire world, as did Osman Pasha in his struggle not to withdraw from Plevne against Russians. This is, in a sense, a metaphorical connotation. Just as Osman Pasha was taken as prisoner to Russians and Plevne was lost due to failure of bringing supporting forces to the field, without support, Erdoğan will also fall and Turkey will not be able to stand against enemies.

With all these narration factors, the movie communicates the message that Turkic states have been reborn from their ashes and continuing their journey to make history. Various leaders have played a major role in these revivals and developments. And the last link of this chain is Recep Tayyip Erdoğan. Turkey is reviving, developing and advancing towards eternity thanks to his sagacity. The movie script is as follows:

"O Turkey! You are now at the bottom of the ladder that resonates in eternity. You are Alparslan, who opened the doors of Anatolia, and Malik-Shah, who exalted his ancestors. Your dream angurs well. You are that giant plane tree passing from Gazi Osman's heart. O Turkey! Know your history so that you shed light to the future. As the Conqueror once said, "Even their dreams shall not access where your power reaches." When your sword arches in the air in defense of your fatherland, Istanbul follows your army in your appeal adorned with love. You are the one conquering not the lands, but hearts. You are the one who dismounted from your horse for the respect of the Almighty even when passing through the desert. Just like Süleyman, you are the one who promised himself victory under all conditions. O Turkey! You will encounter armies and tyrants. But remember, you are the soldier of Abdulbamid who defeated those with dreams on false grounds. You are the Phoenix! You are hope arising in Bandirma and the shield in the War of Independence. Even when your bumble body departs this life, your republic will live forever. O Turkey! Look in the horizon! Protect your history, your ancestors, your brother. Give your hand now! Let the strongest era begin! We shall leave bebind fight, sorrow and the understanding that goes as "We cannot escape our destiny." It is Turkey's Era to renew, fly into passion and run at full gallop for Stability, Future, Unity, Benediction and Wealth!"

\section{The Message Delivered by the Discourse of the Script}

In the movie, Tayyip Erdoğan addresses Turkey with his own discourse. The introductory sentence, "O Turkey! You are now at the bottom of the ladder that resonates in eternity," underlines that Turkey is now entering a period more important than previous stages in the history. Therefore, it is indicated that the decision which shall be made by the nation is critical at the beginning of this journey that extends towards eternity. Even though the movie starts with Turks' entrance to Anatolia, it is expressed that the term of Erdoğan marks "a new beginning" for Turkey which will live forever. Thus, this is regarded as the starting date of Turkey and Turkish presence in Anatolia and Rumelia. This emphasis constitutes an advance response to possible criticism that may follow with the question why the movie started with the year 1071 
instead of going back to the first Turkic state. Indeed, the mythological meaning of Phoenix matches with Gokturks in that Ilterish Qaghan saved Turks after the Gokturk State collapsed and became lost in China and established the Kutluk (Gokturk II) State.

Erdoğan prefers to address all who support or stand against him by saying " $O$ Turkey?? by underlining the importance of the current period for the country and asks endorsement on the grounds of national sentiments and interests. The technique of animation is used in literary terms. In other words, Turkey is deemed and addressed as a live being throughout the movie.

The second sentence refers to entrance of Turks to Anatolia saying, "You are Alparslan, who opened the doors of Anatolia, and Malik-Shah, who exalted his ancestors." It is thereby emphasized that Turkey came into being in the persons of Alparslan and Malik-Shah during the Seljuq Empire. "O Turkey! Know your history so that you shed light to the future. As the Conqueror once said, "Even their dreams shall not access where your powver reaches." When your sword arches in the air in defense of your fatherland, Istanbul follows your army in your appeal adorned with love." Spectators are encouraged to remember their history with these phrases and recommended to direct their future on the basis of this historical experience which is deep enough to open up new horizons that nobody can even dream, just as Mehmet the Conqueror underlined.

In the next sentences, "You are the one conquering not the lands, but hearts. You are the one who dismounted from your horse for the respect of the Almighty even when passing the desert. Just like Suleyman, you are the one who promised bimself victory under all conditions," Turkey is resembled to courageous, visionary and victorious sultans such as Mehmet the Conqueror, Sultan Selim the Stern and Suleyman the Magnificent. Thus, it is underlined that Turkey has many moral traits originating from its history such as sagacity, courage, love for the Prophet, capturing hearts and reverence to Allah.

The call, "O Turkey! You will encounter armies and tyrants. But remember, you are the soldier of Abdulhamid who defeated those with dreams on false grounds," is used to warn the electorate indicating that Turkey may well encounter armies and tyrants in the future as it did in the past. It is implied for the Turkish electorate to elect Erdoğan who is a leader akin to Abdulhamid in order to stand against any such army or tyrant. Otherwise, they would regret as those who stood against Abdulhamid did. Poet Riza Tevfik expressed his emotions and regret in this regard as follows:

"We were lunatics, not you.

We dreamt on false grounds,

We were not only lunatics, but impudent people,

We spitted to the side of our ancestors' Qibla!"

The expressions, "You are the Phoenix! You are hope arising in Bandirma and the shield in the War of Independence. Even when your bumble body departs this life, your republic will live forever," refer to the foundation of Republic of Turkey and Mustafa Kemal Atatürk, uttering that even though Atatürk is not here, his gift of republic will continue to exist, while supporters of secular republic are encouraged to vote for Erdoğan without hesitation. With this emphasis, Erdoğan protects Atatürk and the Republic Period and negates the claims of those who strive to form a negative perception against him. An analogy is set between the collapse of the Ottoman Empire and Phoenix, indicating that the reborn bird is the Republic of Turkey. In fact, it is observed that the feathers of this bird were flying in the air before the Bandirma Ferry set sail. With this expression, Erdoğan explicitly underlines that arguments initiated by certain political parties such as CHP (Republican People's Party) saying that the history of Turkey started in 1923 are wrong. Accordingly, 1923 is the year when the phoenix was reborn from its ashes. And this phoenix has come to today by always rising from its ashes. And from now on, it will be immortal. The AK Party lays the foundation of this immortality as stated in the next sentences.

The words, "Give your hand now! Let the strongest era begin!" represent Phoenix as the Turkish nation being reborn from its ashes and looking in the world from the vault of heaven. This also symbolizes Prof. Dr. Osman Turan's "Ideal of World Dominance by Turks." It is communicated that this can only be actualized under the leadership of Recep Tayyip Erdoğan.

With the final statements, "O Turkey! Look in the horizon! Protect your history, your ancestors, your brother. Give your hand now! Let the strongest era begin! We shall leave behind fight, sorrow and the understanding that goes as "We cannot escape our destiny." It is Turkey's Era to renew, fly into passion and run at full gallop for Stability, Future, Unity, 
Benediction and Wealth!" voters are asked to look at their history and protect their nation and country. These expressions also mean that everyone living in this country is bound by fraternity, while Turkey is also decisive in protecting all brother countries. The term of AK Party is a period of renewal, rearing and gallopade, which is a metaphorical expression referring to horses rearing and running at full gallop (metaphor) as Turkey will accelerate in advancement. Therefore, development is significant for maintaining order in the future of the country. Voting for the AK Party is not only a regular voting activity in ballots. It is, in a sense, a duty and responsibility. This period built by AK Party is one that is the same with the periods explained in the movie and is named after 'Turkey's Era.' It is therefore impossible to separate Republic of Turkey from the Ottomans or the Seljuqs. Letters A and K are given in bold and different colors within the phrase "Turkey's Era" to indicate that this period was initiated by the AK Party. Hence, it is emphasized that Turkey is reborn with the AK Party, which is the last link in the historical process shown in the movie.

It can be argued that the word "brother" in the expression "protect your brother" refers to Erdoğan himself, calling voters to protect and support him.

In the above vocalization, major projects conducted during the AK Party period are also shared and then the camera zooms in a stage where Erdoğan appears. Erdoğan looks forward and the point he shows with his finger turns into "Turkey's Era" emblem in a Phoenix figure. The letters AK in this expression are in bold darker color giving the message that the Phoenix represents the rise of Turks by the AK Party. The savior of all birds according to the legend, Phoenix is now the AK Party as the savior of Turks. There is also a sub-meaning referring to the fact that the AK Party constitutes Turks themselves as the birds in the legend ended up being the savior Phoenix itself.

\section{Visual Signs, Symbols and Metaphors}

As it can be understood from the script, the movie starts with Sultan Alparslan and ends with visuals showing the AK Party's services. Timing per stage is as follows: 18 seconds to the Great Seljuq Empire, 61 seconds to the Ottoman Empire, 21 seconds to the foundation of the Republic, 21 seconds to Recep Tayyip Erdoğan and 21 seconds to services provided by the AK Party.

Phoenix may be uttered as the most important visual element used in the movie since the script is built upon the mythological meaning of this bird. Analogy is set between this mythological figure and the history of Turks indicating that even though Turks established many states under different names throughout their history, they cannot be erased from the history. In other words, it is expressed via the phoenix metaphor that the Turkish nation will always be reborn out of its ashes and never cease to exist.

The most important symbol of the movie is Phoenix that accompanies the story from the very beginning till end. The movie starts with sunrise, which symbolizes a new beginning and fresh hopes. Then, Phoenix rises from inside the sun and gets closer to spectators. a waving flag appears in $15^{\text {th }}$ second. One looking at the west and the other to the east, the double-headed eagle is the symbol of Seljuqs. Then comes the period of the Ottoman Empire.

The next scene shows a plane tree rising from the heart of Osman Gazi who was the founder of the Ottoman Empire. Plane tree is a long-living tree with roots going deep. History books refer to following information with regard to this dream by Osman Gazi: He wanted to have some rest in his tent during a military expedition. He realized there was Koran in his tent, and he took the holy book started to read it. He fell asleep after reading for six hours. These six hours are evaluated as an indication of six centuries of rule. Certain scholars interpreted this dream that Osman Gazi would establish a large state and under the plane tree he saw, many tribes and phratries would come together.

In the next scene, a cavalier commander, Mehmet the Conqueror appears. He proceeds until a certain point and then stops to unsheathe his sword. In the horizon, Istanbul's city walls from the Byzantine period appear together with the Marmara Sea.

Next, many mounted troops appear from distance. This scene depicts Sultan Selim the Stern who dismounted from his horse when passing through the desert due to respect for the Almighty. Various resources explain this situation Sultan Selim the Stern experienced in his military expedition to Egypt as follows: The Ottoman army set off towards Egypt and encountered the Sinai Desert as a natural obstacle. As Sultan Selim the Stern dismounted from his horse when passing through the desert, viziers, beys and cavalrymen also dismounted from their horses and started walking since no one could ride a horse while the sultan himself was walking. Very nimble and majestic, Sultan Selim the Stern walked by looking ahead 
in a deep awe. Viziers and soldiers got curious. They consulted the maid of honor, chatmate and confidant of the sultan, Hasan Can to learn what happened. Hasan Can approached the sultan and asked: "What has happened my Sultan, the entire army is curios and concerned. Why is our Great and Wealthy Sultan walking on his feet?" In great morale and awe, Sultan Selim the Stern turned to Hasan Can and replied: "How can we ride our borses when our Prophet, the Sultan of two worlds, is walking on his feet ahead us, Hasan Can?"

Sultan Selim Khan walked for a while and then got on his horse. Others followed him and they passed through the insurmountable Sinai Desert in only thirteen days. This desert had not received any rainfall for nearly a century and when this army was passing through the desert, it started to rain.

In the next scene, Süleyman the Magnificent is playing chess when expressing that he promised victory to himself under any and all conditions. In the background, the Danube River and its surroundings are depicted.

As people wearing traditional Ottoman clothes appear on the screen, Erdoğan’s words, “... O Turkeey! You will encounter armies and tyrants?" are voiced. Following this sentence, Abdulhamid, who overcame these obstacles, is seen to arrive at the Palace.

Then Mustafa Kemal is shown from his back to depart by Bandırma ferry to reach Samsun, demonstrating the eternity of the republic founded after the War of Independence. In this scene, the feathers of the Phoenix fly in the air.

These various historical things are given in the movie function as metonomy to summarize their period. For instance, Bandirma ferry is the symbolic indicator of the independence of Republic of Turkey. At the same time, this ferry is a metonomy showcasing the ferries of the time. Similarly, military vehicles and equipment are metonomies referring to weaponry of the time.

The Phoenix in the movie flies through strong leaders, heroes at times of important historical developments. The fact that it flies over Tayyip Erdoğan deems him in the same position as other strong leaders. This indicates he is destined to make history as other strong leaders, as well.

\section{French Socialist Party "La France Unie"}

The French election campaign film "La France Unie" was produced for 1988 elections campaign by the socialist party of the country. It was for the re-election campaign of the then President FrancoisMitterrand. The film has used quite informal but unique way of presentation for political advertisement. It has efficiently ordered a few popular French art history portrays, photographs, newspaper and movie cuttings with the fast music in the background to show the modern history of the France.

The very first visual of the film is a portrait of Bastille, the infamous French prison that was the symbol of French royal authority and control over the common French people. The attack on prison is said to be the start of French revolution. It was built in 1300s as a fortress during the 100 years' war. Its purpose was protection of Paris but by the 1700 it became the state prison where King Louis XVI jailed political prisoners. The rebels/ revolutionaries/ attackers of Bastille were the member of French social class that used to be called the third estate in the society. According to the history the suppressed third estate citizens were afraid of an attack by the army to crush the rising political say of the people. So in the preparation for any potential attack and get some arms the third estate invaded the Bastille, which was a success. In the attempt on $14^{\text {th }}$ July the revolutionaries toppled the status quo and beheaded the governor de Launay. The historians write the breaking down of Bastille gave the commoners enough courage against so called nobles of the French society that ended on a successful public revolution. Due to the great importance of the act the world famous French revolution get celebrated on the date of Bastille invasion, the July 14. And moreover the participants of the invasion are considered as the heroes of the nation and have the title of "Vainqueurs of the Bastille" (Winners of the Bastille).

Then there is the slogan of democratic France; "Liberte, Egalite, Fraternite" (Liberty, Equality, Solidarity). We see flashes of the "common class" rising against the monarchy, storming the Bastille and agitating during the revolution.

Next the "Declaration des droits de l'homme et du citoyen" is shown, the popular declaration text written on 26 August 1789. It submits the liberties and freedom which is the right of every man as an individual human being and also the right he has over the ruling government. This declaration was the base for the modern French constitutional law. 
A person travelling in a hot air balloon is the first ever man flight which was done on September 19, 1783 by Joseph-Michel and Jacques-Etienne Montgoflier, the two French brothers. Next is the poster of Napoleon Bonaparte who was a French military leader. He successfully led numerous campaigns during the French revolution for almost a decade, 1804-1814. The arc de triomphe is shown which is an homage to the lives lost during the French revolution and the Napoleonic Wars.

We then see the beginning of the French railway, which occurred in 1823. The first rails were set up for mining, and thus there are people with hammers in the video. The railway system was proposed to Napoleon in 1814. In 1835 the first line became operational for passengers.

There are also brief glimpses of the French slave trade. According to the history around 2 million Africans were sold into slavery only in the $18^{\text {th }}$ century, making France the third largest slave trader in the world. But beautifully that inhumane act has been covered by the portray of Francois-Dominique Toussaint Louverture (1743-1803), the military leader who led a revolutionary movement to free the African slaves during the Haitian Revolution, an anti-slavery movement against French colonisation in Saint-Domingue.

Next, there is the presentation of industrial revolution and prosperity in Europe in general and particularly in France. The people are forging iron and steel and spinning jenny (1764) an English invention is also shown in the film. Portraits of few prominent French scientists/ figures like Marie Curie, the Nobel Prize winner for her work on radiation, Gustave Eiffel who built the Eiffel tower in 1889 are also given space. Then the revolution in the aviation sector with a picture of a plane is shown. In France, the first fixed-wing flight was made by Kuois Bieriot in the year 1909. A car portraying the emergence of the French automotive industry is also there.

Meanwhile the film reaches to the $20^{\text {th }}$ century that begins with the pictures of First World War. There are the glimpses of the French film industry which suffered heavy losses during the World Wars. The iconic image of the Man on the Moon from the French film, le Voyage dans la Lune, is prominently shown. A 1902 production was directed by Georges Melies and got great popularity all over the Europe. Images of the transition of the cinema are also shown. In which "Gaumont", the oldest film Company of the world is shown to take the ownership, as founder of the field. The company was founded by Leon Gaumont in 1895. Modern art and architecture also has been taken in the political communication film. "L'exposition Internationale des Arts Decoratifs et industriels modernes" which was an international exhibition of modern decorative and industrial arts is shown that held in Paris in 1925. First of its kind international art fair was held between April to October 1925 to highlight modern styles of art, architecture, furniture, glass and jewellery. Then the names of Mistinguett and Jeanne Florentine Bourgeois (1875-1956) are shown that are big names of stage and music respectively.

Later there are images of trains which are more modern than before. Prosper and socially progressive society is presented by sports activities in which running and annual men's bicycle race tour de France is shown. The traditional bicycle race started in 1903.

There is also courtesan performing visuals from the Moulin Rouge, a cabaret, founded in 1889. Famous actress Mistinguett also performed there. Another famous name associated with the Moulin Rouge is Adelaide Hall.

Later the civil unrest of May 1968 is presented, which was sparked by French students against capitalism, consumerism, imperialism and other rising injustices in the society. The then president Charles de Gaulle even fled France for some time, fearing the degree of unrest and mega protests in France.

Then there is representation of revolution in the basic pay and holidays. The 'Holiday with Pay Convention" of 1936 stands as first declaration for number of paid annual holidays by ILO convention.

Later there is Hitler, and pictures related to the destruction of Second World War and how that influenced the world and art of the Europe. There is Peruvian Waltz and the jazz, Citroen logo on a car. The Citroen was established in 1919 by Andre-Gustave Citroen.

There are also images that depict the French colonization of Algeria from 1830 to 1962 in which tens of hundreds Europeans flocked to Algeria to settle there down. However extreme unrest and genocide of almost a million Algerians at the hand of the French brought out the Algerian War of Independence (1954 to 1962) which finally gave the African Muslim society liberty, eventually. Then there is again the 
representation of May 1968 event, the revolution of the aviation industry with the Concorde, and more modern images of cycling.

There are also posters and images depicting the feminist movement in France which started during French revolution and ended in 1944 by the right for women to vote. The movement continued into the 90s in which women demanded to be treated as equal citizens to men in addition to the right of abortion.

There is also space for character of Apteryx, an internationally famous French comic, first written in 1959.

While going to the end the French symbols Eiffel Tower, the Champs Elysee and the Musee du Louvre are shown as lit-up to attach with the progress and stability in the Mitterrand presidency. Continuation of great projects like space exploration, French metro system and high speed trains are shown. Big breakthroughs of Francois Mitterrand from 1981 to 1995, especially in international and European politics are presented in the film. In which American President Ronald Reagan and British Prime Minister, Margaret Thatcher are prominent. Mitterrand has been well shown as European Leader who has developed the national role of France not only in the European Economic Community but also at the world stage.

\section{Conclusion}

These movies primarily represent the understanding of development and progress of political leadership of both parties. Every organization or movement of thought may have a peculiar understanding of historical conscious and progress. For example, the paradigm of progress in modernism is based on materialistic developments. Nonetheless, progress is a multi-faceted concept covering science, arts, sports, thoughts, infrastructure, urbanization and all other fields.

In many of his speeches, Tayyip Erdoğan underlines that opinion leaders and architects of this country are Anatolian saints, Rumi, Yunus Emre, Haji Bektash Veli, Akshamsaddin and other men of heart. However, it cannot be argued that this spirit is reflected in the movie. It is clearly observed that this movie presents a very limited and shallow understanding of progress. As a matter of fact, the movie does not refer to Turkish scientists, saints like Rumi, Yunus Emre, sportsmen or opinion leaders but only gives place to visuals of roads, bridges, tunnels and dams.

In this movie called Zümrüdü Anka/Phoenix, the AK Party's emphasis on Turk-Islam is evident. Attention is drawn to Turkey's deep history based on the culture of conquest and it is underlined that Turkey's history goes beyond the year 1923. Indeed, this fact is proven by Erdogan's remarks in the program "Understanding Abdulhamid" in his $100^{\text {th }}$ memorial. Erdoğan is reported to utter during the memorial that "Some people persistently try to claim that this country's history started in 1923. Some people stubbornly put effort to severe us from our roots and our eternal values..." He continued, "Republic of Turkey is the continuation of the Ottomans" (www.gazetekarinca.com, Retrieved: 28.10.2018). Looking from this perspective, this introduction film is observed to be compatible with and even consolidate these ideas uttered by Erdoğan in recent time.

According to the AK Party's idea of Turkey, the Turkish history started with the entrance of Turks to Anatolia in 1071. Turks existed before this year and established various states; however these are excluded from the movie since these states were founded outside the Anatolian geography.

Whatever Alparslan, Malik-Shah, Osman Gazi, Mehmet the Conqueror, Sultan Selim the Stern, Süleyman the Magnificent, Sultan Abdulhamid and Mustafa Kemal Atatürk meant for this country and nation, Recep Tayyip Erdoğan bears the same meaning for the AK Party. In addition, the AK Party gains meaning on the basis of the history and claims an important mission. For this reason, the party invites all voters regardless of their ideology, ethnic origin, etc. to vote for the AK Party. This is, indeed, a duty and responsibility for Turkey's eternity. Instead of causing conflict and disintegration among voters, Erdoğan aims with these discourses to encourage them to unite in solidarity and act together for the future of the country.

Nonetheless, the movie could have given place to successful people in the fields of science, arts, sports and other disciplines contributing to this country's development. Furthermore, heroes and heroines who fought in wars could have been shown in order to provide a more comprehensive view to the history of Turkey. 
When it comes to the comparison of both films it can be claimed that the French film is much more rich and broad not only in the content but the message as well. Although the French film starts by the bloody political event of revolution but quickly shifts to the national and international socio-political development. French nation has been presented as a successful successor of monarchy and feudal system with liberty, equality and the value of solidarity. Then role of France in Africa also has been presented as a civilizational growth factor for the continent by showing the anti-slavery French military leader Toussaint Loussaint.

Then besides some show of infrastructural development most of the focus has been on social development, where scientific inventions from Air traveling sector to the mass transit projects, locally produced cars, prominent contributions in the fields of cinema and other arts, basic sciences fields etc. are much focused in the film. While doing it French film has not ignored the actors behind all this development. From Madam Curie to the Bourgeois all major contributors have been well regarded in the campaign film.

Besides presenting the progressive social moves, socialist party campaign film also has not ignored the national movement against abusive nature of the capitalist system in the country. For that representation the young students of universities from 1968 protests against the culture of consumerism, imperialism and other social injustices have been shown in the film. Then the contributions in the prominent international laws like International Labor Organization Convention and Holiday with pay convention, women right etc. have been shown as a national contribution for humanity. By watching all the visuals one could develop the cognition that French nation has great fighting spirit against cruelty and injustices, does not matter what it costs.

In short by analyzing the films one can easily conclude that AK party definitely needs paradigm shift from infrastructural development to the social and latest technological development in their campaign content. Because the young generation is particularly engaged through mobile and more interested in knowledge economy than the roads and other old style development or mega structures.

\section{References}

Ackerman, B., \& Ayres, L. (2002). Voting with dollars: A new paradigm for campaign finance. Virginia: R. R. Donnelley and Sons, Harrisonburg.

Alterman, E. (2004). When presidents lie: A history of official deception and its consequences. New York: Penguin Group.

Ascher, W. \& Hirschfelder-Ascher, B. (2005). Revitalizing the political psychology. New Jersey: Lawrence Erlbaum Associates, Inc., Publishers.

Duymaz, A. (1998). Anadolu ve Balkan Türklerinin halk anlatmalarında mitolojik bir kuş: Zümrüdüanka. Bahkesir Üniversitesi Sosyal Bilimler Enstitïsü Dergisi, 1(2), 91-97.

Eskier, U. (2019). Zümrüdü Anka (Simurg) Efsanesi. https://www.makaleler.com/zumrudu-anka-simurg-efsanesi, Retrieved on Mar. 3, 2019

Esser, F., \& Pfetsch, B. (2004). Comparing political communication: theories, cases and challenges. New York: Cambridge University Press.

Gurevitch, M. \& Blumler, J. G. (2004). State of the art of the comparative political communication research: Poised by maturity? Comparing Political communication: Theories, Cases and Challenges. New York: Cambridge University Press.

Hovland, C. I. (1959). Reconciling conflicting results derived from experimental and survey studies of attitude change. American Psychologist, 14(1), 8-17.

Halper, S., \& Clarke, J. (2004). America alone: The neo-conservatives and the global affair. New York: Cambridge University Press.

Johnson, D. W. (2001). No place for amateurs: How political consultants are reshaping American democracy. London: Routledge.

Lau, R. R., \& Redlawsk, D. P. (2006). How voters decide: Information processing during election campaign. New York: Cambridge University Press.

McNair, B. (2003). An introduction to political communication. New York: Routledge Press.

Motta, M. P., \& Fowler, E. F. (2016). The content and effect of political advertising in US campaigns. Oxford Research Encyclopedia of Politics. Retrieved on Mar. 13, 2019, http:// oxfordre.com

Maarek, P. J. (2005). Political communication in new era. New York: Routledge Press

Norris, P. (2016). Global political communication: Good governance, human development and mass communication. Comparing political communication: Theories, cases and challenges. New York: Cambridge University Press.

Simurg Zümrüdü Anka Kuşu Türk Mitolojisi, https://www.dogaustu.net/mitoloji-tarih/simurg-zumrudu-anka-kusuturk-mitolojisi.html, Retrieved on Mar. 19, 2019

Stout, L. W. (2006). Time for a change: Ideal leadership series. Shippensburg: Destiny Image Publishers, Inc.

Tenpas, K. D. (2003). Presidents as candidates: Inside the whitehouse for the presidential campaign. London: Routledge Press. 
Tansü, Y. E. \& Güvenç, B. (2017). Mitolojik kuşlar üzerine düşünceler (Phoenix, Garuda, Simurg, Karakuş, Anka). In Y. E. Tansü \& M. Biçici (Eds.). Doç. Dr. Numan Durak. Aksoy Anısına (pp. 783-806). Gaziantep, Gaziantep University.

\section{TÜRKÇE GENİ̧̧ ÖZET}

Bu çalısmada Fransız Sosyalist Partisi'nin 1988 yapımı "La France Unie” ve AK Parti’nin 2016 yapımı "Anka Kuşu” isimli Başkanlık Seçimi temalı filmleri iki siyasi partinin tarihe ve kalkınmaya yaklaşımları açısından analiz edilmiştir. "La France Unie" başlıklı film 1789 Fransız devrimiyle başlamakta ve Fransızların sosyal, siyasi, askeri, ekonomi, bilim, kültür, sanat, spor, edebiyat vs. alanlarında elde ettiği başarıları ve uygarlık bakımından kazanımlarını kapsamaktadır. "Anka Kuşu” ise 1071 Malazgirt Zaferi ile başlamakta; Selçuklular, Osmanlı İmparatorluğu'nun kuruluşu, İstanbul'un fethi, Yavuz Sultan Selim'in Mısır seferi, Türkiye Cumhuriyeti'nin kuruluşu ile devam etmekte ve AK Parti iktidarı döneminde yapılan yatırımlarla sona ermektedir.

Modernizmin ilerleme anlayışı maddi gelişmelere dayanmaktadır. Oysa gelişme çok yönlü bir kavram olup bilim, kültür, sanat, spor, düşünce, altyapı ve şehirleşme gibi yaşamın birçok alanını da kapsamaktadır. Her lider veya siyasi hareket de farklı tarihsel şuur ve ilerleme anlayışına sahiptir. AK Parti Genel Başkanı, Recep Tayyip Erdoğan'ın siyasi kariyeri süresince yaptığı konuşmalar dikkate alındığında ekonominin yanı sıra özellikle eğitim, bilim ve kültür konularına da ağırlık veren bir lider olduğu söylenebilir. Erdoğan konuşmalarında sıkça Mevlana, Hacı Bektaş Veli, Yunus Emre ve Akşemseddin gibi manevi şahsiyetlerden ve bilim tarihine önemli katkılar sunan Ali Kuşçu, İbni Sina, Biruni, Cezeri, Uluğ Bey ve Harezmi gibi bilim insanlarından söz ederek Türk tarihinin inşasındaki ilmi ve manevi boyutun önemine de vurgu yapmaktadır. AK Parti'nin hazırladığı tarih odaklı bir reklam filminde, Erdoğan'ın bu tarih ve ilerleme anlayışının vücut bulması beklenebilirdi. Oysa filmde anlatılan ilerleme anlayışı son derece sınırlı olup, tarih boyunca bilim, eğitim, kültür, maneviyat, spor, sanat gibi alanlarda önemli başarrlar elde etmiş ve Türk medeniyetine katkı sunmuş şahsiyetlere, savaşlardaki kahramanlara yer verilmemiştir. Sadece fetihler ve otoyol, köprü, tünel ile baraj gibi altyapı alanında elde edilen başarılar dile getirilmektedir.

Kimi Cumhuriyetçiler Türkiye'nin tarihini 1923’ten itibaren başlatırken, AK Parti 1071 tarihinde, Türklerin Sultan Alparslan'ın ordusuyla Malazgirt'ten Anadolu'ya girişiyle başlatmakta ve Anadolu Selçukluları, Osmanlı İmparatorluğu ve Türkiye Cumhuriyeti ile devam ettirmektedir. Erdoğan, Türkiye'nin tarihini 1srarla 1923 'ten başlatanların iyi niyet taşımadıklarına ve amaçlarının Türk milletini tarihinden ve geçmişle bağlarından koparmak olduğuna vurgu yapmaktadır. Bu anlamda "Anka Kuşu"nun Erdoğan'ın bu bakış açısını yansıttığı görülmektedir. Filmde Alparslan, Melik Şah, Fatih Sultan Mehmet, Yavuz Sultan Selim, Abdülhamid Han ve Mustafa Kemal Atatürk Türklerin ve Türkiye'nin bu tarihsel yolculuğunda ne gibi bir katkı yapmışsa, bu zincirin son halkasında yer alan AK Parti’nin de aynı yönde önemli katkı sunduğu mesaj1 verilmektedir. Dolayısıyla Recep Tayyip Erdoğan bu liderler kadar önemli bir lider olarak konumlandırılmaktadır. Filmde sergilenen tarih anlayışı bağlamında AK Parti, bütün vatandaşları bir amaç uğrunda birleştirmeye ve tüm seçmenlerin oyunu almaya çalışmıştır.

Fransız Sosyalist Partisi’nin hazırladığı "La France Unie" adlı filmin ise, tarihe bakış açısının, içerik ve mesaj açısından daha kapsamlı ve zengin olduğu görülmektedir. Filmde her ne kadar kanlı Fransız devrimiyle başlansa da hızla ulusal ve uluslararası toplumsal ve siyasal gelişmelere geçilmektedir. Fransa'nın monarşiden sonra 'özgürlük, eşitlik ve kardeşlik' sloganıyla ulus devlete geçtĭgi, Afrika'da köleliğe son vererek sivil ve uygar yaşamın gelişmesinin önünü açtı̆̆1 mesaj1 verilmektedir. AK Parti’nin "Anka Kuşu” filminin aksine, son üç yüz yılda altyapı alanında sağlanan ilerlemenin yanı sıra, fizik, kimya ve matematik gibi temel bilimlerde; uçak, tren, otomobil, uzay gibi değişik sanayi alanlarında; eğitim, spor, sanat, kültür ve siyaset alanlarında elde edilen gelişmeler ve şahsiyetlere yer verilerek Fransa'nın gelişmesinde bütün bu kişilerin ve kazanımların katkısının olduğu ifade edilmektedir. Fransız sineması ve sanatçılar da görmezden gelinmemiştir. 1968 olaylarına; insan hakları, işçi hakları ve kadın hakları gibi birçok alanda verilen mücadelelere yer verilmektedir. Bütün bu tarihsel sürecin son halkasında lider olarak François Mitterrand yer almaktadır. Bu filmi izleyenler bugünkü Fransa'nın bütün Fransızların eseri olduğunu kolaylıkla anlayabilir. Dolayısıyla ulusal birliktelik, dayanışma ve birlikte başarı mesajı verilmektedir.

AK Parti’nin, bu filmde görüldüğü gibi, sadece askeri alandaki ve altyapıdaki gelişmeleri kapsayan tarih anlayışını bırakarak eğitim, bilim, kültür, spor, teknoloji, toplumsal alanları vs. kapsayan bir tarih anlayışına geçmeye ihtiyacı olduğu söylenebilir. Özellikle genç nesil otoyol, baraj vs. gibi altyapısal düzenlemelerden ziyade teknoloji, spor, eğitim, kültür politikaları ve uygulamaları gibi konulara önem 
DEVRAN \& SHAHZAD

The Comparison of Two Different Election Campaign Films in Terms of Their Approaches towards National History and Development

vermektedir. AK Parti iktidarları döneminde bu alanlarda da önemli ilerlemeler sağlanmış olmasına rağmen parti filmlerinde yeterince yansıtılmamaktadır. Sonuç olarak, genç nesillerin beklentileri, öncelikleri ve bakış açılarının da dikkate alınarak bütün bu gelişmelere ve başarılarıyla toplumun takdirini toplayan şahsiyetlere de seçim kampanya filmlerinde yer verilmesi gerekmektedir. 